\section{ECONOMICS}

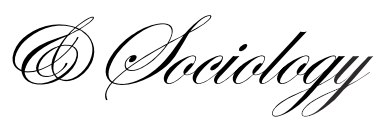

\title{
WHAT CAN TAX REVENUES TELL US ABOUT THE ECONOMIC ACTIVITY OF REGIONS?
}

\begin{abstract}
The main goal of this paper is to provide an analysis of the relationships among selected indicators of economic activity of regions (GDP, unemployment) and regional tax revenues obtained from taxes imposed on economic activity (VAT, income taxation) in the Czech Republic, with a detailed analysis of VAT. Our methodology is based on correlation analysis (both the Pearson's and the Spearman's correlation coefficients) using data from the official statistics of the Czech Republic. The main idea of the paper is that regional tax revenues should give us a picture of the economic activity of companies, residents and entrepreneurs in these regions. Based on the results, we can say that there is a statistically significant positive relationship between regional VAT revenues and the value of regional GDP, and a statistically significant negative relationship between regional income taxes revenues and regional unemployment.
\end{abstract}

DOI: $10.14254 / 2071-$

789X.2016/9-1/8

JEL Classification: E62, H25,

Keywords: VAT, Income Taxation, Macroeconomic Indicators, H71, R11

Regions, Czech Republic.

\section{Introduction}

The economic activities of particular countries or regions can be expressed by different macroeconomic indicators (GDP, unemployment, inflation and balance of trade, or their components). Particular indicators show us the economic health of particular countries or regions which we can use to compare the development of these regions during a selected period.

Policy makers use actual economic data for the purpose of economic policy planning and management. However, usually there is a problem with macroeconomic data delay, especially in the case of regional macroeconomic indicators. As there are tax offices on the regional level (represented by regional and organizational units), we can assume that regional policy makers can obtain some up-to-date economic data from these tax offices - for example, regional tax revenues, number of tax returns etc. This tax-based information can serve as an additional source of information for regional management and decision making. 
The question is: what can regional tax revenues and other tax-based information tell us about the current economic activity of regions? The authors focus on possible relationships among selected indicators of economic activity of regions (GDP, unemployment) and regional tax revenues obtained from taxes imposed on economic activity (VAT, income taxation) and regional tax returns (VAT). The research is provided for the Czech Republic because regional macroeconomic and tax data are available for the authors and the tax system of the Czech Republic has the same features as standard European tax systems. Although our analysis is performed on the regions of the Czech Republic, the methodology can be applied to another European countries.

Economic activity taxation in the Czech Republic is based on the following legislation: Act No. 586/1992 Coll., on income taxes (Czech Republic, 1992) and Act No. 235/2004 Coll., on value added tax (Czech Republic, 2004). The trends in particular tax rates development and fiscal indicators development are shown in Table 1.

Table 1. Overview of tax indicators in the period 2005-2015

\begin{tabular}{|c|c|c|c|c|c|c|c|c|c|c|c|}
\hline & 2005 & 2006 & 2007 & 2008 & 2009 & 2010 & 2011 & 2012 & 2013 & 2014 & 2015 \\
\hline VAT rates & $\begin{array}{l}5 ; \\
19\end{array}$ & $\begin{array}{l}5 ; \\
19\end{array}$ & $\begin{array}{l}5 ; \\
19\end{array}$ & $\begin{array}{l}9 ; \\
19\end{array}$ & $\begin{array}{l}9 ; \\
19\end{array}$ & $\begin{array}{l}10 \\
20\end{array}$ & $\begin{array}{l}10 \\
20\end{array}$ & $\begin{array}{l}14 \\
20\end{array}$ & $\begin{array}{l}15 \\
21\end{array}$ & $\begin{array}{l}15 \\
21\end{array}$ & $\begin{array}{l}10 \\
15 \\
21 \\
\end{array}$ \\
\hline PIT rates & $\begin{array}{l}15 \\
20 \\
25 \\
32\end{array}$ & $\begin{array}{l}12 ; \\
19 ; \\
25 ; \\
32\end{array}$ & $\begin{array}{l}12 ; \\
19 ; \\
25 ; \\
32\end{array}$ & 15 & 15 & 15 & 15 & 15 & 15 & 15 & 15 \\
\hline CIT rates & 26 & 24 & 24 & 21 & 20 & 19 & 19 & 19 & 19 & 19 & 19 \\
\hline ETR CIT & 22.7 & 21.0 & 21.0 & 18.4 & 17.5 & 16.7 & 16.7 & 16.7 & $16.7^{*}$ & - & - \\
\hline $\begin{array}{l}\text { Tax quota in } \\
\text { total }\end{array}$ & 35.7 & 35.3 & 35.9 & 34.4 & 33.4 & 33.6 & 34.6 & 35.0 & $34.9^{*}$ & - & - \\
\hline $\begin{array}{l}\text { Tax quota- } \\
\text { State Budget }\end{array}$ & 24.8 & 24.5 & 25.0 & 23.8 & 22.8 & 23.0 & 23.8 & 24.1 & $23.9^{*}$ & - & - \\
\hline $\begin{array}{l}\text { Tax quota - } \\
\text { budgets of } \\
\text { municipalities }\end{array}$ & 5.2 & 5.0 & 5.1 & 4.9 & 4.7 & 4.7 & 4.8 & 4.8 & $4.8^{*}$ & - & - \\
\hline
\end{tabular}

*Preliminary estimate.

Source: Czech Republic (1992), Czech Republic (2004), Denis et al., eds. (2014). VAT Value added tax, PIT - Personal income tax, CIT - Corporate income tax, ETR - Effective tax rates.

Regarding VAT, tax rates were changed five times in the period 2005 to 2015 (for more information about VAT in the Czech Republic (see e.g. Široký et al., 2014 or David, 2015). Focusing on income taxation, the most significant change is visible in the case of personal income tax (PIT). Beginning 1 January 2008 there has been a flat tax rate in place for all individuals within the Czech Republic (calculated from the so-called "super gross wage"). Regarding legal entities, the tax rate of corporation income tax (CIT) decreased from $26 \%$ in 2005 to $19 \%$ in 2015 (Schelleckens, ed., 2015). Primarily due to a reduction in the statutory CIT, the effective tax rate of corporate tax calculated according to the Deveroux methodology (discussed in more detail in Denis et al., eds., 2014) decreased in the analysed period by 6 percentage points (from $22.7 \%$ to $16.7 \%$ ).

The tax quota of the Czech Republic (as the most widely used indicator of the tax burden) was fluctuating around the average of EU28 in the analysed period. Rows 6 and 7 show the distribution of the total tax quota to the state budget and budgets of municipalities. 
The supplement consists of funds of social insurance, health insurance funds and payments to the EU budget.

Figure 1 and 2 illustrate the development of the key macroeconomic indicators (unemployment and GDP) in all of the regions in the Czech Republic in the period 20052012.

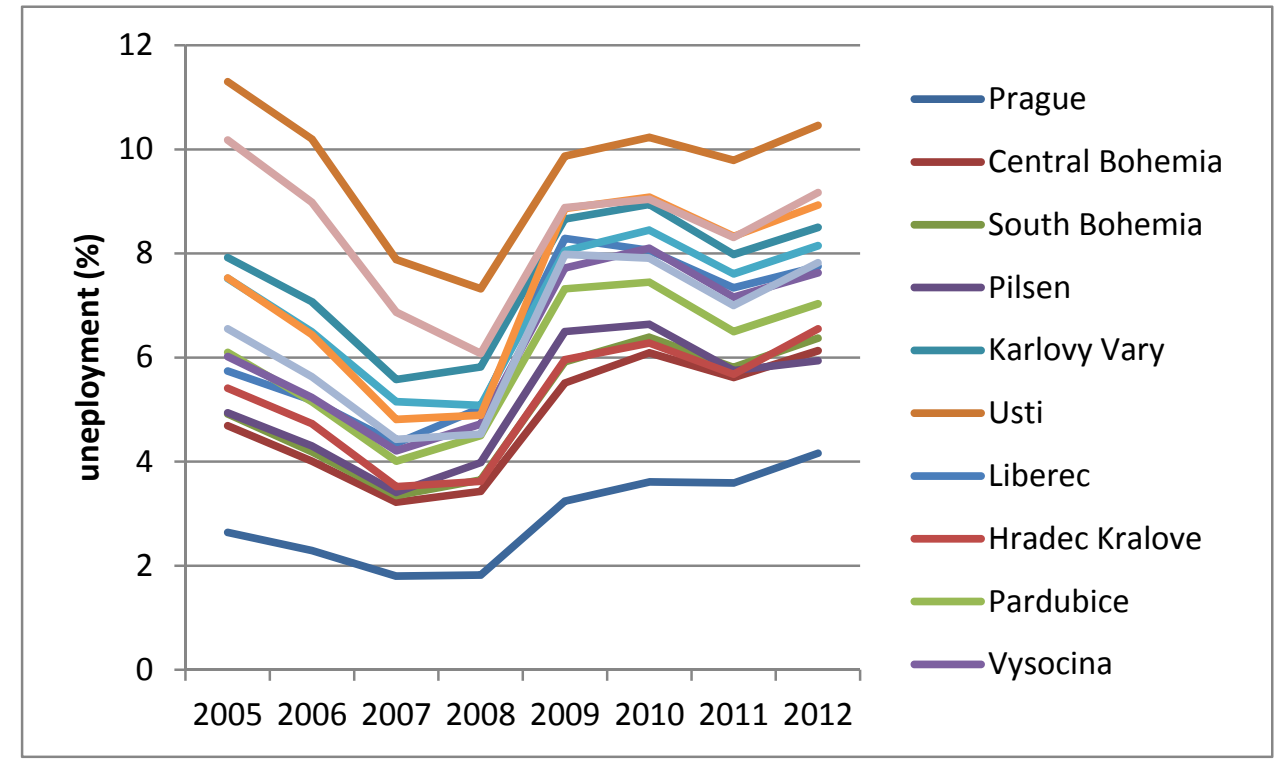

Figure 1. The development of unemployment between 2005 and 2012 Source: MLSA, 2015; authors.

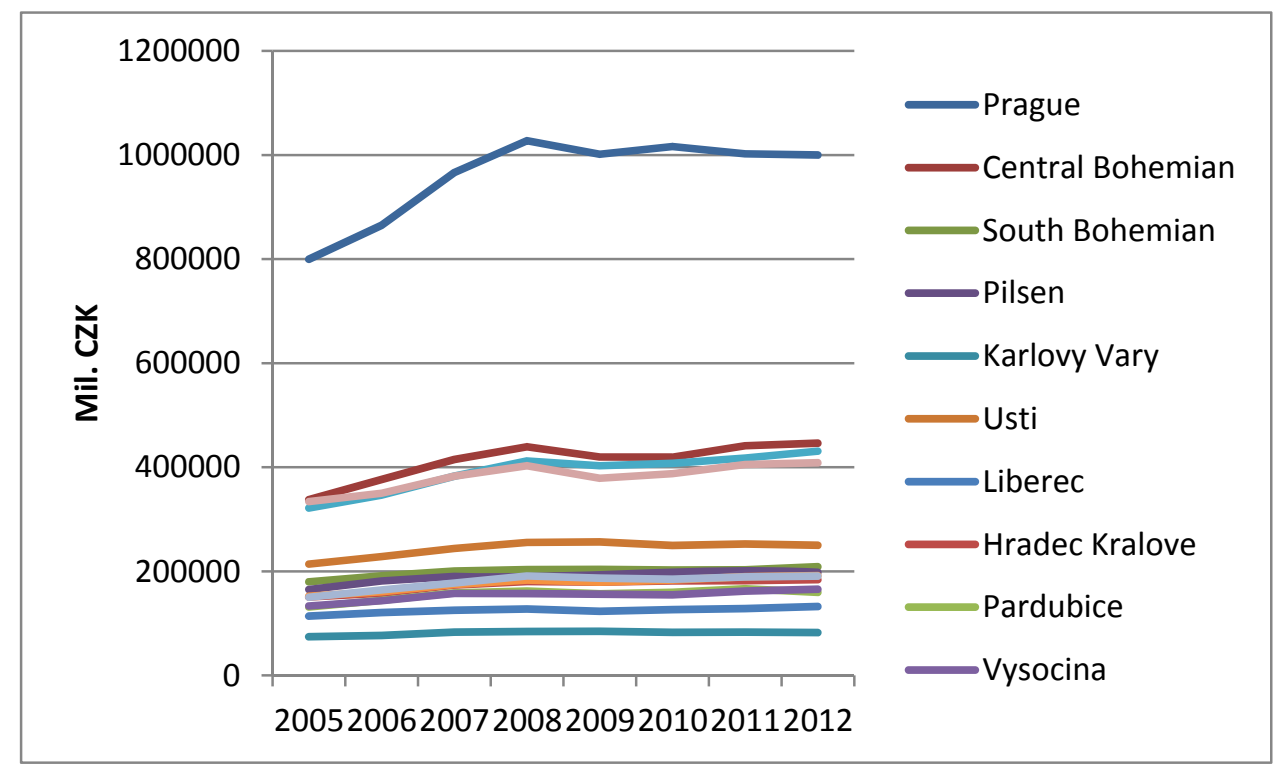

Figure 2. The development of GDP between 2005 and 2012 Source: CZSO, 2015; authors.

You can see that all of the regions show similar trends in the analysed period. Moreover, the impact of the economic crises in 2008 is also visible, since unemployment increased significantly in 2009 in all regions of the Czech Republic and GDP decreased in the same year in almost all of the regions within the Czech Republic. 
Regarding regional tax revenues, we can present the differences among particular regions in the Czech Republic using graphical expression. Figure 3 shows the differences among regional tax revenues in 2012.

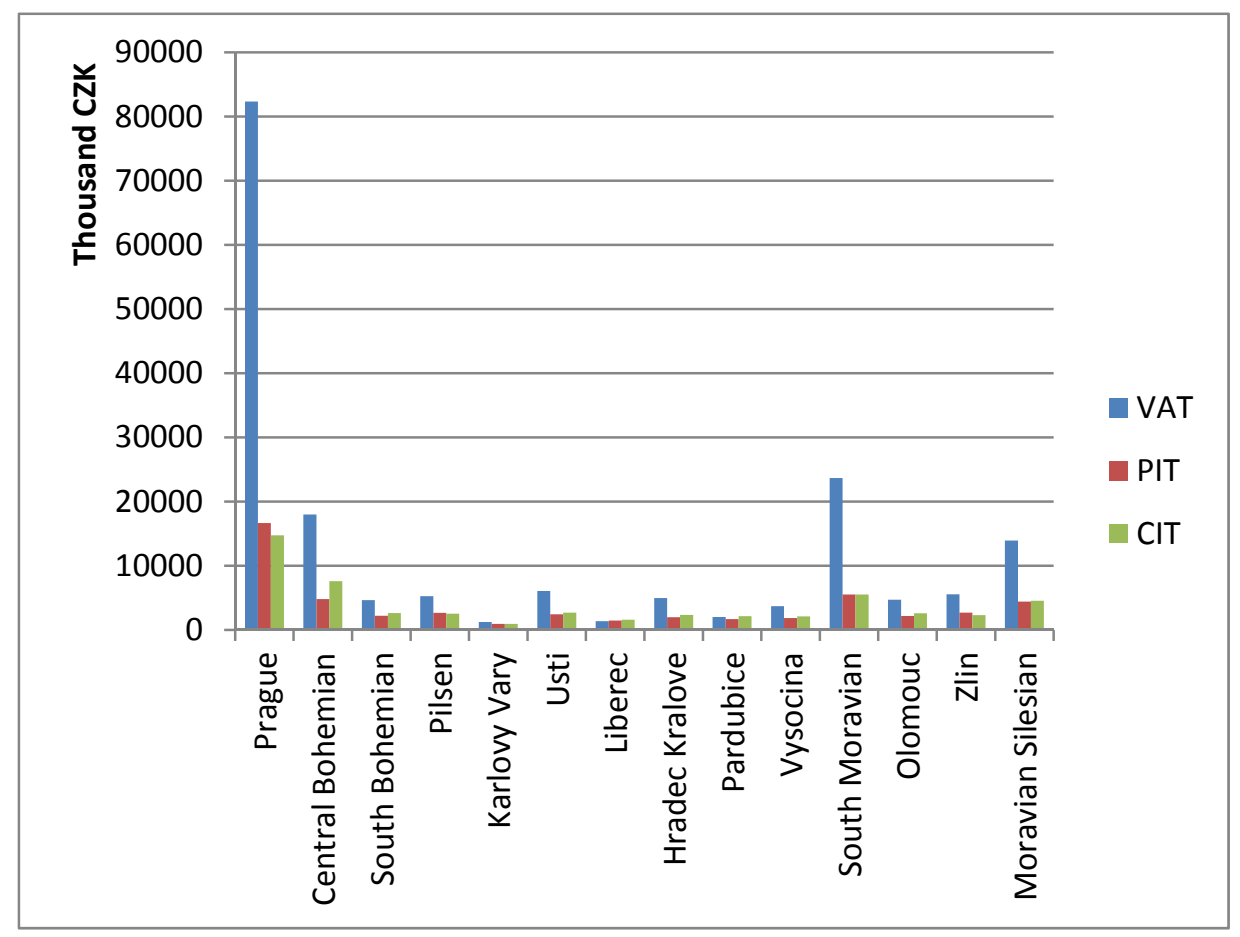

Figure 3. Tax revenues in regional breakdowns in Y2012

Source: FACZ, 2015; authors.

We can see that VAT revenues represented the most important part of tax revenues in almost all of the regions in 2012. However, Prague achieved the highest VAT revenue, mainly due to the allocation of the seats of many large corporations. Both CIT and PIT revenues had similar importance within particular regional tax revenues. The share of SME in the total number of active enterprises in the Czech Republic in 2012 was $99.86 \%$. The share of the added value of SME in 2012 was $53.81 \%$ (for more about SME in the Czech Republic see e.g. Belas et al., 2014).

Finally, Figure 4 illustrates the development of the number of tax returns for VAT in all regions in the period 2005-2011. 


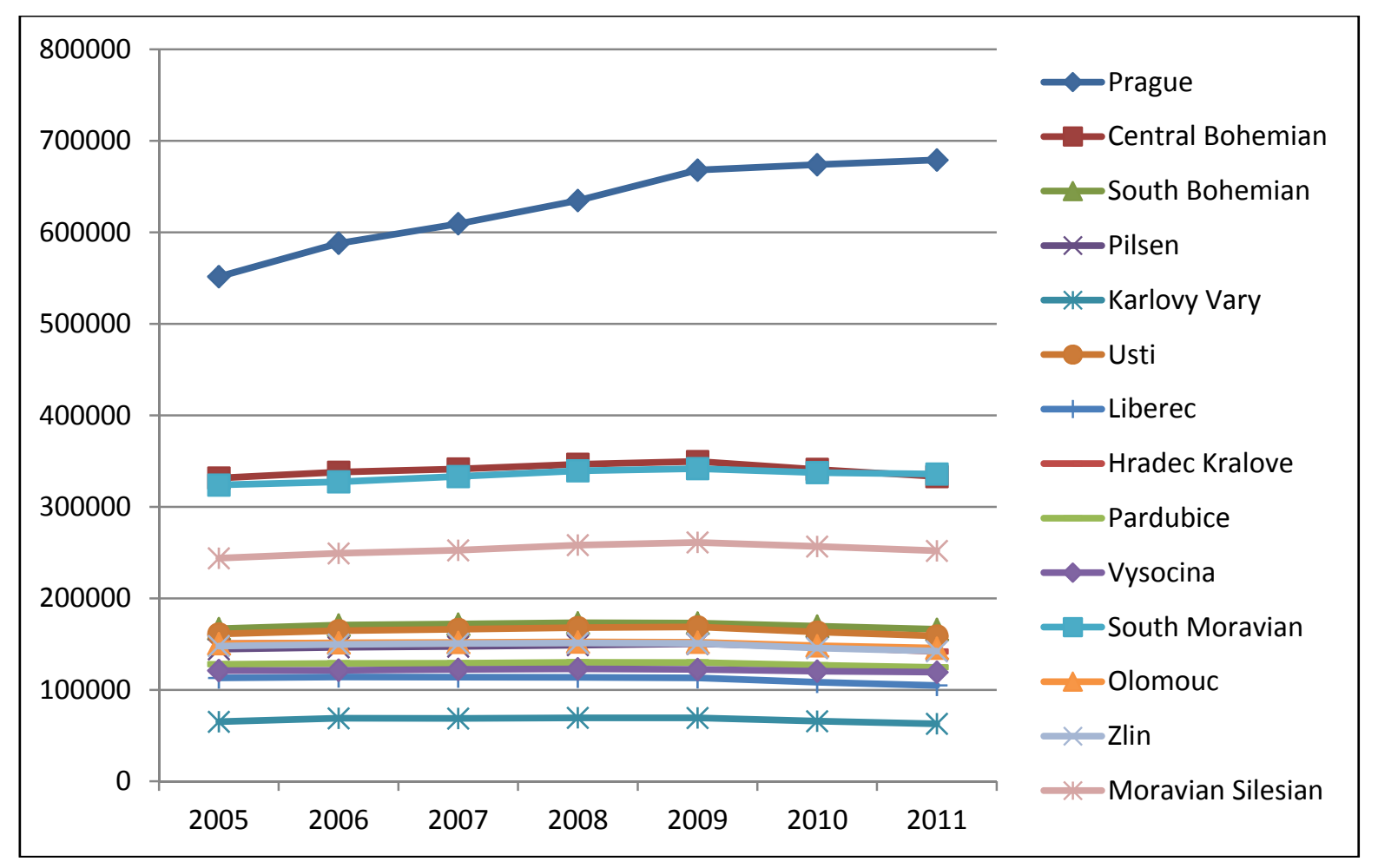

Figure 4. Development of number of tax returns for VAT Source: FACZ, 2015; authors.

It is obvious that all of the regions show similar trends in the analysed period. The exception is Prague, where we can see a significant increase between 2005 and 2009 and mild increase in years 2010 and 2011. Focusing on other regions, the number of tax returns has been slowly declining since 2009 .

\section{Literature Overview}

Generally, the relationships between regional tax revenues and economic growth are the subject of research provided mainly by the neoclassical economists dealing with the growth models, in more details for example in Barro and Sala-i-Martin (2004) or Widmalm (2001). Economic theory assumes that the relationship between indirect taxation and economic growth is negative, for example Mendoza et al. (1997); moreover specific excise taxes generate less distorting effects on economic growth than the general consumption tax, as stated in Widmalm (2001), Schenk et al. (2015) or Melnyk (2015), focusing on Czech literature Kubátová (2010) and Vítek (2008).

Currently, there are also many scientific studies dealing with issues of regional economic health and focusing on particular macroeconomic indicators. For example Arhipova and Rudusa (2005) focused on development of territories within countries in transition period, mainly in Latvia. They analysed GDP, unemployment level, the number of economically active enterprises and businesses, nonfinancial investments and the amount of income tax. The results of their research should contribute to strategic cooperation for the improvement of entrepreneurial processes. Martinčík (2008) indicates that the most known reasons for the differences between particular regions can be historically divided to the ways of creation of GDP in particular regions, demographic characteristics, natural conditions, transportation infrastructure and volume of direct foreign investments. Cebula and Clark (2014) provided preliminary analysis for OECD countries and non-G8 OECD nations; they focused their 
research on study of the impact of economic freedom, regulatory quality and relative burden of taxation on the level of GDP in period 2003-2007. They analysed the relationships between the degree of economic freedom and GDP, the level of regulatory quality and GDP and the overall tax burden and GDP. Reshina and Vocish (2011) deal with budgetary policy and interbudgetary relations at the regional level in Latvia, particularly the taxation capacity (financial potential) across the regions. Szarowska (2011) analysed the effect of tax burden on economic growth in the countries within the European Union. The analysis is performed on a panel data of 24 EU countries in a period 1995-2008, methodology is based on panel regression with fixed effects. Author presents statistically significant negative effect of both tax burden and direct tax on GDP growth, moreover negative correlation between corporate income taxes and GDP growth. Folster (2002) focused on relationship between taxation and self-employment, using a panel data from OECD countries and Sweden. He presents a strong negative correlation between the tax burden and the share of self-employed within total employment. Tepperova et al. (2012) deal with the hypothesis that the revenue from taxes that selfemployed must pay is affected by macro variables such as change in GDP, unemployment, or the differential in taxation and social security contributions between employees and selfemployed. The analysis is based on data from 28 European countries in the period 1995-2009.

Currently, there is a lack of studies focused on the relationships between revenues obtained from the regional economic activity taxation and the regional economic development. Moreover, the authors did not find any study focused directly on an analysis of regional tax revenues as economic indicators for the purposes of policy decision making.

The authors presented partial results of current analysis at the scientific conferences in Zlín (Zimmermannová et al., 2015) and Prague (Zimmermannová et al., 2015). This paper presents the final version of the analysis after incorporation of all comments and recommendations from both conferences.

\section{The main objectives of the paper}

The main goal of the paper is to provide analysis of relationships between selected indicators of economic activity of regions (GDP, unemployment) and regional tax revenues obtained from taxes imposed on economic activity (VAT, income taxation) in the Czech Republic, with detailed analysis of VAT.

For the purposes of this main goal, the authors define the following 3 hypotheses:

H1: There is a statistically significant relationship between regional tax revenues and the value of regional GDP.

$\mathrm{H} 2$ : There is a statistically significant relationship between regional tax revenues and the regional unemployment.

H3: There is a statistically significant relationship between regional VAT returns and the value of regional GDP.

\section{Data and methodology}

\subsection{Data}

For the purposes of analysis of relationship between regional tax revenues and economic activity of regions, the following data are used: GDP in the regional breakdown, share of employed in the regional breakdown - indicator compares the number of job applicants (aged 15-64 years) to all residents (in this age group), value added tax (VAT) revenues and income tax revenues (PIT and CIT) in the regional breakdown, fulfilled in tax forms. All of the data represent period 2005-2012. 
For the purposes of the detailed VAT analysis, the following data are used: GDP in the regional breakdown, value added tax (VAT) revenues in the regional breakdown and number of tax returns of VAT in the regional breakdown. All of the data represent period 2005-2011. Regional number of tax returns for VAT are available only until year 2011.

The main data sources are the following: Czech Statistical Office (CZSO, 2015), Ministry of Labour and Social Affairs (MLSA, 2015), and Financial Administration of the Czech Republic (FACZ, 2015).

\subsection{Methodology}

Generally, the following classical methods are used: input data and indicators examination, comparison of particular characteristics at regional level, deduction and synthesis for the purposes of conclusions formulation. The research presented in this article is also based on the study of current legislation of the Czech Republic.

For the purposes of achieving the main objective of the paper, the authors use the correlation analysis. Correlation coefficients can take the value in the interval $<-1 ; 1>$, whereas the positive or negative values signal the dependence direction. The absolute value expresses the strength of the dependence. The dependence can be studied as linear (the Pearson's correlation coefficient) or nonparametric (the Spearman's correlation coefficient).

The Pearson's correlation coefficient is defined as

$$
r=\frac{\sum_{i=1}^{n}\left(x_{i}-\bar{x}\right)\left(y_{i}-\bar{y}\right)}{\sqrt{\sum_{i=1}^{n}\left(x_{i}-\bar{x}\right)^{2} \sum_{i=1}^{n}\left(y_{i}-\bar{y}\right)^{2}}}
$$

and the Spearman's correlation coefficient as

$$
\rho=\frac{6 \sum_{i}^{n}\left(p_{i}-q_{i}\right)^{2}}{n\left(n^{2}-1\right)},
$$

These correlation coefficients were successfully applied by the authors in their previous research connected with the impacts of particular economic instruments of public economy in the Czech Republic (Zimmermannova, 2012; Zimmermannova and Mensik, 2013) or in research focused on the dependence among various variables - income structure, health and social insurance and personal income tax; GDP per capita, net disposable household income per capita, and the mean gross monthly wage in the Czech regions (Kvicalova et al., 2014).

For the purposes of this paper, the correlation analysis is performed for the period 2005-2012 as a whole, the detailed analysis for VAT for the period 2005-2011.

\section{Results}

\subsection{Regional tax revenues vs economic activity of regions}

Firstly, we should focus on the relationships between selected indicators of economic activity of regions within the Czech Republic (GDP, unemployment) and regional tax 
revenues obtained from taxes imposed on economic activity (VAT, income taxation - PIT and CIT), based on linear dependence. The following Table 2 shows us the results of correlation analysis based on the Pearson's and Spearman's correlation coefficients for regional VAT revenues, regional GDP and regional unemployment. The amount of observations was 8 for each indicator and region.

Table 2. VAT revenues vs economic activity indicators

\begin{tabular}{lcccc}
\hline & \multicolumn{2}{c}{ VAT and GDP } & \multicolumn{2}{c}{ VAT and share of unemployed } \\
\cline { 2 - 5 } & Pearson & Spearman & Pearson & Spearman \\
\hline Prague & 0.650 & 0.643 & $0.716^{*}$ & $0.714^{*}$ \\
\hline Central Bohemian & $0.893^{* *}$ & $0.786^{*}$ & 0.106 & 0.173 \\
\hline South Bohemian & $0.797^{*}$ & 0.667 & 0.341 & 0.241 \\
\hline Pilsen & $0.761^{*}$ & 0.476 & 0.305 & 0.381 \\
\hline Karlovy Vary & 0.271 & 0.643 & 0.040 & 0.119 \\
\hline Usti & $-0.857^{* *}$ & -0.595 & 0.166 & -0.143 \\
\hline Liberec & -0.530 & -0.548 & -0.454 & -0.190 \\
\hline Hradec Kralove & $0.964^{* *}$ & $0.881^{* *}$ & 0.192 & 0.286 \\
\hline Pardubice & -0.642 & $-0.714^{*}$ & $-0,516$ & -0.595 \\
\hline Vysocina & 0.617 & 0.262 & 0.545 & 0.405 \\
\hline South Moravian & $0.943^{* *}$ & $0.881^{* *}$ & -0.071 & 0.024 \\
\hline Olomouc & $0.752^{*}$ & 0.595 & 0.176 & 0.262 \\
\hline Zlin & $0.843^{*}$ & $0.714^{*}$ & 0.275 & 0.500 \\
\hline Moravian Silesian & $0.817^{*}$ & 0.619 & -0.681 & -0.667 \\
\hline
\end{tabular}

*Correlation is significant at the 0.05 level. ${ }^{* *}$ Correlation is significant at the 0.01 level.

Source: own work.

Regarding the relationship between regional value added tax (VAT) revenues and GDP, we can see positive statistically significant relationship in the most of the regions. The values of Pearson's correlation coefficient are higher than 0.8 in five of fourteen cases and higher than 0.7 in eight of fourteen cases. However, there is also negative statistical significant relationship in the Usti region - the development of GDP was similar as in the other regions (see Fig. 3), but values of VAT revenues were decreasing from year 2006. Focusing on the Spearman's correlation coefficient, its values are lower than in case of the Pearson's correlation coefficient and they are statistically significant only in five cases. We can see also negative correlation in three regions; however, the value of correlation coefficient is statistically significant only in one of them - the Pardubice region. There has been significant slump of VAT revenues during the analysed period. It can be caused by movement of the seats of regional companies to other regions for the purposes of lower frequency of financial controls.

Analysing the relationship between VAT revenues and unemployment, it is obvious that the Pearson's correlation coefficient is significant only in case of the Prague region, other values of correlation coefficient are weak; moreover it is not clear, whether their mutual relationship is positive or negative. The results are almost similar also in case of the Spearman's correlation coefficient. It follows that the development of the examined variables are mutually independent and different in particular regions. 
The following Table 3 shows us the results of correlation analysis based on the Pearson's and Spearman's correlation coefficients for regional CIT revenues, regional GDP and regional unemployment. The amount of observations was 8 for each indicator and region.

Table 3. CIT revenues vs economic activity indicators

\begin{tabular}{lcccc}
\hline & \multicolumn{2}{c}{ CIT and GDP } & \multicolumn{2}{c}{ CIT and share of unemployed } \\
\cline { 2 - 5 } & Pearson & Spearman & Pearson & Spearman \\
\hline Prague & -0.333 & -0.095 & $-0.889^{* *}$ & $-0.952^{* *}$ \\
\hline Central Bohemian & -0.411 & -0.690 & $-0.938^{* *}$ & $-0.952^{* *}$ \\
\hline South Bohemian & -0.344 & -0.595 & $-0.919^{* *}$ & $-0.857^{* *}$ \\
\hline Pilsen & -0.677 & $-0.762^{*}$ & $-0.905^{* *}$ & $-0.786^{*}$ \\
\hline Karlovy Vary & -0.020 & 0.333 & $-0.735^{*}$ & $-0.714^{*}$ \\
\hline Usti & -0.260 & -0.214 & -0.512 & -0.524 \\
\hline Liberec & -0.652 & -0.714 & $-0.884^{* *}$ & $-0.738^{*}$ \\
\hline Hradec Kralove & $-0.754^{*}$ & $-0.857^{* *}$ & $-0.749^{*}$ & $-0.810^{*}$ \\
\hline Pardubice & -0.223 & -0.381 & $-0.841^{* *}$ & $-0.714^{*}$ \\
\hline Vysocina & -0.073 & -0.143 & $-0.951^{* *}$ & $-0.929^{* *}$ \\
\hline South Moravian & -0.504 & -0.619 & $-0.856^{* *}$ & $-0.857^{* *}$ \\
\hline Olomouc & -0.433 & -0.571 & $-0.910^{* *}$ & $-0.952^{* *}$ \\
\hline Zlin & -0.347 & -0.190 & $-0.839^{* *}$ & $-0.833^{*}$ \\
\hline Moravian Silesian & -0.401 & -0.452 & -0.508 & -0.333 \\
\hline Corrlation
\end{tabular}

${ }^{*}$ Correlation is significant at the 0.05 level. ${ }^{* *}$ Correlation is significant at the 0.01 level.

Source: own work.

Focusing on corporate income tax (CIT) revenues and GDP, there is low level of Pearson's correlation coefficients. However, we can see the direction of their mutual relationship, which is negative. Regarding Spearman's correlation coefficients, we can see that the correlation is significant only in two cases - Pilsen and Hradec Kralove regions.

Regarding the relationship between CIT revenues and unemployment, we can see strong negative statistically significant relationship in almost all of the regions. The values of the Pearson's correlation coefficient are higher than 0.8 in ten of fourteen cases (for regions Prague, Central Bohemian, South Bohemian, Pilsen, Liberec, Pardubice, Vysocina, South Moravian, Olomouc and Zlin). The values for Karlovy Vary and Hradec Kralove are higher than 0.7. The values of Spearman's correlation coefficients shows, that there is strong negative statistically significant relationship between the variables in almost all of the regions; it is similar as in case of the Pearson's correlation coefficient. The values of the Spearman's correlation coefficient are higher than 0.8 in eight of fourteen cases and higher than 0.7 in twelve of fourteen cases.

The following Table 4 shows us the results of correlation analysis based on the Pearson's and Spearman's correlation coefficients for regional PIT revenues, regional GDP and regional unemployment. The amount of observations was 8 for each indicator and region. 
Table 4. PIT revenues vs economic activity indicators

\begin{tabular}{lcccc}
\hline & \multicolumn{2}{c}{ PIT and GDP } & \multicolumn{2}{c}{ PIT and share of unemployed } \\
\cline { 2 - 5 } & Pearson & Spearman & Pearson & Spearman \\
\hline Prague & -0.624 & -0.738 & -0.627 & -0.619 \\
\hline Central Bohemian & -0.316 & -0.429 & -0.622 & -0.524 \\
\hline South Bohemian & -0.545 & -0.548 & $-0.767^{*}$ & $-0.857^{* *}$ \\
\hline Pilsen & -0.196 & -0.595 & $-0.929^{* *}$ & $-1^{* *}$ \\
\hline Karlovy Vary & -0.458 & -0.333 & -0.666 & $-0.905^{* *}$ \\
\hline Usti & -0.544 & -0.595 & -0.222 & -0.214 \\
\hline Liberec & -0.452 & -0.405 & $-0.861^{* *}$ & $-0.905^{* *}$ \\
\hline Hradec Kralove & -0.558 & -0.619 & -0.692 & $-0.786^{*}$ \\
\hline Pardubice & -0.339 & -0.452 & $-0.797^{*}$ & $-0.905^{* *}$ \\
\hline Vysocina & -0.221 & -0.167 & $-0.807^{*}$ & $-0.905^{* *}$ \\
\hline South Moravian & -0.458 & -0.452 & -0.611 & -0.548 \\
\hline Olomouc & -0.449 & -0.452 & -0.700 & -0.690 \\
\hline Zlin & -0.575 & -0.452 & $-0.726^{*}$ & $-0.786^{*}$ \\
\hline Moravian Silesian & -0.474 & -0.333 & -0.173 & -0.024 \\
\hline Corration
\end{tabular}

*Correlation is significant at the 0.05 level. ${ }^{* *}$ Correlation is significant at the 0.01 level.

Source: own work.

Focusing on personal income tax (PIT) revenues and GDP, there is low level of both Pearson's and Spearman's correlation coefficients. However, we can see the direction of their mutual relationship, which is negative; the results are similar as in case of CIT, but the relationship between variables is weaker.

Regarding personal income tax (PIT) revenues and share of unemployed, we can see strong negative statistically significant relationship, the values of the Pearson's correlation coefficient are higher than 0.7 in six of fourteen cases, the values of the Spearman's correlation coefficient are higher than 0.7 in eight of fourteen cases.

\subsection{Detailed focus on VAT}

Since the previous chapter shows us significant relationship between regional GDP and VAT revenues, we should focus on it in more details and prove, that this relationship is not connected only with the number of tax returns for VAT.

The following Table 5 shows us the results of correlation analysis based on both the Pearson's and Spearman's correlation coefficients for regional VAT revenues, regional number of tax returns for VAT and regional GDP. The amount of observations was 7 for each indicator and region (from 2005 to 2011). Regional number of tax returns for VAT are available only until year 2011 . 
Table 5. Detailed focus on VAT

\begin{tabular}{lcccc}
\hline & \multicolumn{2}{c}{ RVAT and NVAT } & \multicolumn{2}{c}{ NVAT and GDP } \\
\cline { 2 - 5 } & Pearson & Spearman & Pearson & Spearman \\
\hline Prague & $0.772 *$ & $0.929 * *$ & $0.898 * *$ & 0.750 \\
\hline Central Bohemian & 0.673 & 0.714 & 0.525 & 0.393 \\
\hline South Bohemian & 0.240 & 0.143 & 0.476 & 0.500 \\
\hline Pilsen & 0.493 & 0.500 & 0.234 & 0.000 \\
\hline Karlovy Vary & 0.058 & 0.250 & 0.204 & 0.607 \\
\hline Usti & -0.163 & -0.107 & 0.404 & 0.536 \\
\hline Liberec & $0.915 * *$ & 0.679 & -0.456 & -0.429 \\
\hline Hradec Kralove & -0.446 & -0.143 & -0.397 & -0.321 \\
\hline Pardubice & 0.664 & 0.321 & -0.206 & -0.143 \\
\hline Vysocina & 0.104 & 0.179 & 0.003 & 0.107 \\
\hline South Moravian & $0.791 *$ & 0.536 & $0.925 * *$ & 0.679 \\
\hline Olomouc & 0.102 & 0.393 & -0.325 & -0.107 \\
\hline Zlin & 0.712 & 0.536 & 0.700 & 0.429 \\
\hline Moravian Silesian & -0.201 & 0.179 & -0.207 & 0.250 \\
\hline Corration is signican
\end{tabular}

${ }^{*}$ Correlation is significant at the 0.05 level. ${ }^{* *}$ Correlation is significant at the 0.01 level. RVAT means revenues of value added tax, NVAT means number of tax returns for value added tax, GDP means gross domestic product. Source: own work.

Focusing on VAT revenues (RVAT) and number of tax returns for VAT (NVAT), there are low levels of Pearson's correlation coefficients (except of Liberec, Prague and South Moravian). We can see no statistically significant relationship between these indicators. Regarding the Spearman's correlation coefficients, the results are similar as in case of the Pearson's correlation coefficient. There is only one region with statistically significant value of correlation coefficient - Prague.

Analysing the relationship between number of tax returns for VAT revenues (NVAT) and GDP, we can say that the Pearson's correlation coefficient is significant only in 2 regions - Prague and South Moravian. Regarding other regions, the values of these correlation coefficients are not statistically significant. Regarding the Spearman's correlation coefficients, we cannot see any statistical significant values.

\section{Discussion}

The main goal of the paper is to provide analysis of relationships between selected indicators of economic activity of regions (GDP, unemployment) and regional tax revenues obtained from taxes imposed on economic activity (VAT, income taxation) in the Czech Republic, with detailed analysis of VAT. As is mentioned previously in the literature overview, the relationships between regional tax revenues and economic growth are the subject of research provided mainly by the neoclassical economists dealing with the growth models (in more details for example in Barro and Sala-i-Martin (2004) or Widmalm (2001)). This research is focused on an application of economic growth issue to the regional level and also includes the other aspects, for example unemployment. The originality of this paper is also determined by analysis of not only the tax rates, but tax revenues at the regional level.

First, we should focus on 3 hypotheses, which were set for the purposes of the main goal achievement. 
H1: There is a statistically significant relationship between regional tax revenues and the value of regional GDP.

We can partially confirm this hypothesis H1.

Regarding the relationship between regional VAT revenues and the value of regional GDP, we can see statistically significant positive correlation in eight regions (Central Bohemian, South Bohemian, Pilsen, Hradec Kralove, South Moravian, Olomouc, Zlin and Moravian Silesian). However, not all regions show similar results, for example the Usti and the Pardubice regions show unusually negative statistically significant correlation coefficients. This can be caused for example due to fluctuations and irregular development of tax revenues during the analysed period (especially significant reduction in tax revenues). We can say that VAT revenues represent the added value within the regional economic activities in most of the regions of the Czech Republic.

Regarding the relationship between regional income tax (PIT and CIT) revenues and the value of regional GDP, we can say that regional income tax (PIT and CIT) revenues are not correlated significantly with the value of regional GDP. Within our analysis, there were noted low and insignificant values of correlation coefficients. It can be caused by regular tax optimization carried out by companies and self-employed. Therefore income tax revenues do not represent the value of regional economic activities in the regions of the Czech Republic.

\section{H2: There is a statistically significant relationship between regional tax revenues and the regional unemployment.}

We can partially confirm this hypothesis $\mathrm{H} 2$.

Regarding the relationship between regional VAT revenues and the regional unemployment, there is no clear relationship between these indicators. The results of the correlation analysis are ambiguous and the correlations are weak. We can say that regional VAT revenues have no relationship with the value of regional unemployment.

Regarding relationships between regional CIT revenues and the regional unemployment, there can be observed statistically significant negative correlation in twelve regions, both in cases of linear and nonparametric relationship (except of only two regions Usti and Moravian Silesian). We can say that the value of regional unemployment is in opposite relation to the production and profits of companies within particular regions.

Regarding correlations between regional PIT and regional unemployment, there is visible only negative nonparametric relationship. Statistically significant negative correlations can be observed in 8 regions.

We can say that it is obvious, that higher regional income tax revenues are connected with lower regional unemployment, in other words we can anticipate that their values go to the diverse direction. Therefore the low share of unemployed persons in regions together with higher number of companies would create additional PIT and CIT revenues.

H3: There is a statistically significant relationship between regional VAT returns and the value of regional GDP.

We can reject this hypothesis $\mathrm{H} 3$.

Based on the results of the correlation analysis, there is positive statistically significant relationship only in 2 regions - Prague and South Moravian; however these regions have the biggest amount of VAT returns in the Czech Republic. We can say that VAT returns indicator and its development can give us no information regarding economic activity of particular regions and its development.

It is obvious that the information about amount of VAT returns in particular regions cannot automatically means the information about the economic activity of these regions. The real economic activity of particular regions can be described by more suitable indicator VAT revenues in particular regions. 
There are weaknesses of the presented research, based mainly on the differences between official seats of particular companies and the place, where the company really operate. However, the results show that in spite of this situation, there can be significant relationship between some of the analysed indicators. Comparing the results with for example Mendoza et al. (1997), we can say that our results are "the other side of the same coin" - the relationship between indirect taxation and economic growth is negative; however higher regional VAT revenues represent higher economic activity of particular regions, expressed officially by regional GDP indicator.

Further research in this area can be focused on an analysis of regional aspects of public finance by applying of complex methods, for example regression analysis, cluster analysis or I-O analysis.

Another way of the following research in our field can be expansion of the analysis to another countries within the EU or the EU as a whole and the international comparison of the results.

\section{Conclusions}

The paper presents the analysis of relationships between selected indicators of economic activity of regions (GDP, unemployment) and regional tax revenues obtained from taxes imposed on economic activity (VAT, income taxation) in the Czech Republic, with detailed analysis of VAT.

The main idea of the paper is that regional tax revenues should give us the picture of economic activity of companies, residents and entrepreneurs in these regions. Although it is generally expected that VAT revenues in particular regions are affected mainly by the number of registered tax payers and the amount of tax returns, our analysis showed that tax revenues can represent economic activity in particular regions. Based on the results, we can say that there is statistically significant positive relationship between regional VAT revenues and the value of regional GDP and statistically significant negative relationship between regional income taxes revenues and regional unemployment. On the other hand, the relationship between regional VAT returns and the value of regional GDP is not statistically significant.

The results show us that the regional tax revenues can serve as an additional source of information about regional economic activity for the purposes of decision making of policy makers on governmental or regional level. Although the analysis is performed for the regions of the Czech Republic, the methodology can be applied also to another European countries.

\section{References}

Arhipova, I., Rudusa, I. (2005), The Entrepreneurial Networks and Regional Development in Latvia, Proceeding of International Conference on Entrepreneurship and Macroeconomic Management, Apr. 28-30, 2005, Pula, Croatia, pp. 8-20. ISBN: 978953-7144-01-2.

Barro, R., Sala-i-Martin, X. (2004), Economic Growth, $2^{\text {nd }}$ Edition, New York etc.: MIT Press, 654 p. ISBN 978-80-262-02553-9.

Belás, J., Bartoš, P., Habánik, J., Novák, P. (2014), Significant Attributes of the Business Environment in Small and Meduim-Sized Enterprises, Economics and Sociology, 7 (3), pp. 22-39. DOI: 10.14254/2071-789X.2014/7-3/2.

Cebula, R. J., Clark, J. R. (2014), The effects of economic freedom, regulatory quality and taxation on the level of per capita real income: a preliminary analysis for OECD nations and non-G8 OECD nations, Applied Economics, 46 (31), pp. 3836-3848. DOI: 10.1080/00036846.2014.943885. 
Czech Republic (1992), Act No. 586/92 Coll., on income taxes, in wording of the respective amendments, In: The Collection of Laws of the Czech Republic, available at: http://www.sbirka.cz. [Accessed: 2015, January 5].

Czech Republic (2004), Act No. 235/2004 Coll., on value added tax, in wording of the respective amendments, In: The Collection of Laws of the Czech Republic, available at: http://www.sbirka.cz. [Accessed: 2015, January 5].

Czech Statistical Office - CZSO (2015), Indicators in regional breakdown, available at: http://apl.czso.cz/pll/rocenka/rocenkavyber.volba?titul=Indicators in regional breakdown\&mypriznak $=\mathrm{RC} \&$ typ $=2 \&$ proc $=$ rocenka.presmsocas \&mylang $=\mathrm{EN} \& \mathrm{jak}=4$ [Accessed: 2015, March 16].

David, P. (2015), Kdo nese břemeno změny sazeb DPH v České republice? EMI (Economics Management Innovation), 7 (1), pp. 3-12.

Denis, C., Hemmelgarn, T., Sloan, B. (eds.) (2014), Taxation Trends in the European Union. 2014 Edition, Luxembourg: Publications Office of the European Union. ISBN 978-9279-35672-8.

Financial Administration of the Czech Republic - FACZ (2015), Tax statistics 2015 - 2012, available at: http://www.financnisprava.cz/cs/dane-a-pojistne/analyzy-astatistiky/danova-statistika [Accessed: 2015, April 21].

Folster, S. (2002), Do lower taxes stimulate self-employment? Small Business Economics, 19 (2), pp. 135-145.

Kubátová, K. (2010), Daňová teorie a politika, 5. vyd. Praha: Wolters Kluwer ČR, 276 s. ISBN 978-80-7357-574-8.

Kvíčalová, J., Mazalová, V., Široký, J. (2014), Identification of Differences between the Regions of the Czech Republic based on the Economic Characteristic, Procedia Economics and Finance, 12C, pp. 343-352. DOI: 10.1016/S2212-5671(14)00354-2.

Martinčík, D. (2008), Ekonomicko-sociální úroveň krajů - komplexní srovnávací analýza, E+M Ekonomie a management, 11 (1), pp. 14-24.

Melnyk, S. (2015), Supply Chain as a Competitive Weapon, In: SMART Conference. January 15-17, 2015, Michigan State University, pp. 15-21.

Mendoza, E. G., Milesi-Ferretti, G. M., Asea, P. (1997), On the ineffectiveness of tax policy in altering long-run growth: Harberger's superneutrality conjecture, Journal of Public Economics, 66 (1), pp. 99-126.

Ministry of Labour and Social Affairs - MLSA (2015), Share of unemployed since 2005, available at: http://portal.mpsv.cz/sz/stat/nz/casove_rady [Accessed: 2015, January 10].

Reshina, G., Vocish, A. (2011), Formation of the budgetary policy at the regional level at the Latvian Republic, Proceedings of International Conference on New Socio-Economic Challenges of Development in Europe, Oct. 7-9, 2010, Univ. Latvia, Riga, Latvia. pp. 247-255. ISBN: 978-9984-45-363-7.

Schelleckens, M. (ed.) (2015), European Tax Handbook 2015, Amsterdam: IBFD. ISBN 97890-8722-313-7.

Schenk, A., Thuronyi, V., Cui, W. (2015), Value Added Tax: A Comparative approach, New York, Cambridge University Press. ISBN 978-1-107-04298-8.

Široký, J., Stř́lková, R., Bánociová, A., Zlaczká, V. (2014), Reflection of the change in VAT rates on selected household expenditures in the Czech Republic and the Slovak Republic (2007-2013), Acta Universitatis Agriculturae et Silviculturae Mendelianae Brunensis, 62 (6), pp. 1465-1474. ISSN 1211-8516. DOI: 10.11118/actaun201462061465.

Szarowska, I. (2011), Changes in taxation and their impact on economic growth in the European Union, Acta Universitatis Agriculturae et Silviculturae Mendelianae Brunensis, 59 (2), pp. 325-332. ISSN 1211-8516. DOI: 10.11118/actaun201159020325. 
Tepperova, J., Vančurova, A., Vitek, L. (2012), Taxation and Self-employment, Proceedings of the 17th International Conference New Role of Public Finance 2012, Prague. pp. 288-297. ISBN 8074780120.

Vítek, L. (2008), Ekonomická analýza zdanění př́jmů, Praha: IREAS, 311 s. ISBN 978-8086684-50-5.

Widmalm, F. (2001), Tax Structure and growth: Are Some Taxes Better than Others? Public Choice, 107 (3/4), pp. 199-219.

Zimmermannova, J. (2012), Ex-post Analysis of Impacts of the Car Registration Fee in the Czech Republic, Transportation Research Part A: Policy and Practice, 46 (9), pp. 1458-1464. DOI: 10.1016/j.tra.2012.07.001.

Zimmermannová, J., Menšík, M. (2013), Ex post analýza zavedení zdanění pevných paliv, zemního plynu a elektřiny, Politická ekonomie, 61 (1), pp. 46-66. ISSN 0032-3233.

Zimmermannová, J., Skaličková, J., Široký, J. (2015), Regional Tax Revenues as the Indicators of Economic Activity of Regions in the Czech Republic, Proceedings of the 7th International Scientific Conference ,, Finance and Performance of Firms in Science, Education and Practice", Tomas Bata University in Zlín, Zlín, pp. 1695-1707. ISBN 978-80-7454-482-8.

Zimmermannová, J., Skaličková, J., Široký, J. (2015), VAT as an Indicator of Economic Activity of Regions in the Czech Republic, Proceedings of the 20th International Conference Theoretical and Practical Aspects of Public Finance, University of Economics, Prague, pp. 296-301. ISBN 978-80-245-2094-0. 